\title{
Low Rates of Tebuthiuron for Control of Sand Shinnery Oak
}

\author{
V.E. JONES AND R.D. PETTIT
}

\begin{abstract}
Tebuthiuron [N-(5-(1,1-dimethylethyl)-1,3,4-thiadiazol-2-yl)-N, $N^{\prime}$-dimethylurea] pellets $(20 \%$ ai) were broadcast at $0.2 \mathrm{~kg}$ increments to $1.0 \mathrm{~kg}$ /ha onto a sand shinnery oak (Quercus havardii) community in west Texas $\left(33^{\circ} 23^{\prime} 52^{\prime \prime} \mathrm{N}\right.$ and $\left.102^{\circ} 46^{\prime} 38^{\prime \prime} \mathrm{W}\right)$. Treatments $\geq 0.4 \mathrm{~kg} / \mathrm{ha}$ reduced oak canopy $98 \%$ and standing crop at least $90 \%$. Grass yield was unaffected by herbicide treatments during the first year. Thereafter, yield on treated areas increased from 420 to $690 \mathrm{~kg} / \mathrm{ha}$ as contrasted to $140 \mathrm{~kg} / \mathrm{ha}$ on the control. Where oak was untreated, grasses became quiescent, due to drought, up to 6 weeks earlier than on treated areas.
\end{abstract}

Sand shinnery oak (Quercus havardii) grows on 1.2 million ha of rangeland in Texas, two-thirds having a canopy of $20 \%$ or more (Deering and Pettit 1971). This plant infests an additional 0.4 million ha in Oklahoma (Mcllvain 1956) and 1.1 million ha in New Mexico (Garrison and McDaniel 1982). Along the precipitation gradient across this species' range, density and stature of oak increases with precipitation and locally with depth of surface sands.

This oak is toxic to livestock and competes with better forages. Presence of it increases livestock production costs because of (1) increased death loss, (2) reduced conception rates and weight gains caused by chronic poisoning, (3) required supplemental or alternative feeds during the most toxic period, and (4) increased managerial costs.

Repeated applications of foliar herbicides or land conversion by deep-plowing have accounted for most control efforts. Risk associated with these techniques and increases in their cost have stimulated research to develop better controls. Use of root-absorbed herbicides has been suggested as a means of improving the reliability, efficiency, and safety of treatment. These herbicides, applied as pellets or granules, reduce the risk of off-target movement; and since they are root absorbed, plant condition at application is not believed as critical as for foliar applied compounds.

Pettit (1975) and Jones et al. (1978) reported that oak could be controlled with pelleted tebuthiuron [N-(5-(1,1-dimethylethyl)-1,3, 4-thiadiazol-2-yl)-N,N'-dimethylurea], a substituted urea. Tebuthiuron at $1.0 \mathrm{~kg} /$ ha or more killed all oak (Pettit 1979) while 2 years after treatment with $0.6-\mathrm{kg} /$ ha stem density decreased over $80 \%$ (Jones et al. 1978). Other oaks are killed or suppressed by this herbicide (Meyer et al. 1978, Meyer and Bovey 1980, Scifres et al. 1981).

Oak-dominated rangelands in Oklahoma produce twice as much grass following single, foliar applications of phenoxy herbicides (Mcllvain and Armstrong 1959, 1963; Greer et al. 1968). Consecutive yearly treatments provide better oak control and result in a tripling of grass production. Production, however, soon declines and stabilizes at twice that of untreated areas (McIlvain and Armstrong 1963). In Texas, grass production increases up to 6-fold the second year after a single foliar herbicide treatment; but since oak regrowth is not suppressed, retreatment is deemed necessary within

\footnotetext{
The authors, at the time of research, were graduate research assistant and associate professor, Department of Range and Wildlife Management, Texas Tech University, Lubbock 79409

This article is Texas Tech University College of Agricultural Sciences Publication No. T-9-376.

Manuscript accepted March 19. 1984
}

\section{3 to 5 years (Scifres 1972).}

Forage increased up to $387 \%$ where pelleted herbicides were used to control oak in the Texas Rolling Plains (Jones et al. 1978). On the more arid Southern High Plains, grass yields tripled where oak yield was reduced $25 \%$ (Pettit 1979). Greater oak control gave a 4-to 9-fold increase in grass.

Data reported here reflect the effectiveness of low rates of tebuthiuron for control of sand shinnery oak. The associated yield of grass is also addressed.

\section{Materials and Methods}

The study was on the Southern High Plains of Texas ( $33^{\circ} 23^{\prime} 52^{\prime \prime}$ $\mathrm{N}$ and $102^{\circ} 46^{\prime} 38^{\prime \prime} \mathrm{W}$ ), about $25 \mathrm{~km} \mathrm{~S}$ and $2.5 \mathrm{~km}$ E of Lehman, Texas. Soils of the study area were Brownfield, Circleback (tentative series), Patricia and Tivoli fine sands. Excluding the Tivoli, these soils differ primarily in the depth of fine sand over a sandy clay loam subsoil. The first 3 soils are classed as Alfisols (Paleustalfs) while the Tivoli is an Entisol (Ustipsamment).

A warm-temperate, semiarid climate typifies the area, though rapid temperature fluctuations, especially during the winter, are common. Precipitation averages $41 \mathrm{~cm}$ and is variable. About $80 \%$ of the precipitation is received from May through October. Frequent winds, high temperatures, and low relative humidity enhance evaporation. The growing season averages 200 days.

A motor-driven "Cyclone" seeder behind a tractor was used to broadcast tebuthiuron pellets ( $20 \%$ ai) onto 2 -ha plots ( 100 by 200 $\mathrm{m})$ at $0.2,0.4,0.6,0.8$, and $1.0 \mathrm{~kg} /$ ha during May 1978 . A functional swath of $16.7 \mathrm{~m}$, offset slightly to the right, was used so that overlap between swaths would help equalize herbicide distribution. Treatments plus a control were assigned in a completely randomized design with 3 replicates. Buffers of $20 \mathrm{~m}$ were left to prevent overlap during application.

Four transects, perpendicular to treatment swaths, were chosen at random across each plot. Along each, 10 random points were permanently marked. Density and canopy cover by species were measured within square $0.25-\mathrm{m}^{2}$ quadrats at each reference point during the spring, summer, and fall from 1978 through 1980. Standing crop was estimated at 10 randomly selected reference points in each plot during the spring, summer, and fall from May 1978 through June 1981 . Square $0.5-\mathrm{m}^{2}$ quadrats were placed at preselected distance and direction from each point to prevent resampling the same area. Herbage was clipped at a $1 \mathrm{~cm}$ height and separated into current year's growth by major species or group (i.e., forbs, shrubs, other grasses) before bagging. Samples were dried at $44 \mathrm{C}$ to a constant water content and weighed.

Density and cover data were subjected to either square-root or arcsin transformation before being analyzed (Steel and Torrie 1960). Data were analyzed using standard analysis of variance or analysis of covariation techniques. Means separation $(P<0.05)$ utilized either Duncan's multiple range test or the least significant difference (LSD) test (Steel and Torrie 1960).

\section{Results and Discussion}

\section{Oak Control}

In 1978, oak defoliated cyclically with defoliation and regrowth 
associated with precipitation events. Little regrowth occurred after leaf drop unless either the soils were wet or an appreciable amount of precipitation was received. New leaves then developed rapidly, but before they were fully expanded, phytotoxic symptoms appeared. Maximum herbicidal effects on oak occurred when soils were wet and when climatic conditions favored high transpiration rates. Plant injury developed more slowly in swath overlap areas and in deeper sands.

Pretreatment canopy cover of oak, through only $17 \%$, accounted for $60 \%$ of the total canopy cover. Oak frequency was $93 \%$ with a density of 12,000 old and 1,600 new (sprouts) shoots/ ha. Standing crop was likewise dominated by oak. On 6 June 1980 standing crop $(1,309 \mathrm{~kg} / \mathrm{ha})$ in untreated areas was $78 \%$ oak and 10,9 , and $2 \%$ for other shrubs, grasses, and forbs, respectively.

By May 1979 density and canopy cover of old oak shoots were reduced in treated areas. In 1980 the mean density of old shoots in the $0.2-\mathrm{kg} / \mathrm{ha}$ and $\geq 0.4-\mathrm{kg} /$ ha treatments was reduced 81 and $96 \%$ with a reduction in canopy of 84 and $98 \%$, respectively.

As oak topgrowth died, rhizome buds broke dormancy; by fall 1978 the density of new shoots was greater than in the control. Herbicide induced mortality reversed this trend by mid 1979. Thereafter the density and canopy of new shoots continued to be lower in areas receiving at least $0.4 \mathrm{~kg} / \mathrm{ha}$ of herbicide.

Current year's standing crop of oak was collected as an alternative assessment of control. From July 1979 through June 1981 tebuthiuron treatments $\geq 0.4 \mathrm{~kg} /$ ha reduced oak standing crop $90 \%$ or more (Table 1). Oak yield was also reduced by the $0.2 \mathrm{~kg} / \mathrm{ha}$ treatment but due to unequal distribution of herbicide, control in individual plots ranged from negligible to near total in a pattern of alternating bands.

This oak produces primarily short shoots on which leaf expansion is rapid. When not damaged by frost or insects, leaves are fully expanded by late May. During the summer drought in 1980 , untreated oak shed $36 \%$ of its leaves as compared to $24 \%$ in 1978 . No effects of the drought were noted in 1979. Leafout in 1981 was normal and foliage was comparable to that of the previous years.

\section{Grass Response}

After removing treatment effect by covariate analysis, grass yield was rarely influenced by the pretreatment canopy or density of grass. Thus all analyses of grass yields use data unadjusted for pretreatment population variables.

Mean grass yields throughout the total study period were greater in treated than untreated areas (Figure 1-a). Maximum yield of 571 $\mathrm{kg} / \mathrm{ha}$ (nearly 4 times that of the control) occurred in the $0.8 \mathrm{~kg}$ / ha treatment. Yield in the $0.2 \mathrm{~kg} /$ ha treatment was 2.5 times greater than in the control.

In 1978, grass yield (Figure 1-b) did not differ among treatments. In more recent samples (Figures $1-c, d, e$ ), yields were consistently greater in treated areas. By late May 1979 grass yields on treated areas had already approached or exceeded the maximum yields recorded during the previous year. Fall 1978 and 1979 grass yields on control areas were comparable ( 239 vs. $231 \mathrm{~kg} / \mathrm{ha}$ ) while on treated areas yields were 600 to $1,500 \mathrm{~kg} /$ ha greater in 1979 .

Early June 1980 grass yields in treated areas were almost 3.5 times ( $417 \mathrm{vs} 120 \mathrm{~kg} / \mathrm{ha}$ ) greater than in the control and nearly 1.2 times greater than at the same period in 1979. Later grass growth was suppressed by the drought that prevailed throughout the summer of 1980 . Fall rains came too late to stimulate additional growth.

Drought-induced quiescence of grasses during 1980 occurred up to 6 weeks earlier in control than in treated areas. From early June through July, grass yield in untreated areas increased only $5 \mathrm{~kg} /$ ha as compared to increases of $34,170,193,130$, and $193 \mathrm{~kg} / \mathrm{ha}$ in each successively higher herbicide rate. The reduction in competitive use of available soil water by oak diminished the effect of drought on herbage species in treated areas.

\section{Management Concerns}

We have observed oak ranges treated with tebuthiuron since 1974. Perennial brush species typically respond to treatment by undergoing cyclic defoliations. Up to 3 years may be required before control stabilizes. No reinfestation has been observed on areas where treatment provided total oak kill. However, a few sand sagebrush (Artemisia filifolia) have reestablished, and may be a management problem in the future. Soapweed (Yucca angustifolia) was not killed by tebuthiuron to $1.0 \mathrm{~kg} /$ ha and also may become a problem.

On the area studied, tebuthiuron did not kill all the oak. Growing on Tivoli soils, it defoliated repeatedly, yet lived. Variability in sand depth, even on level topgraphy, caused a mottling effect of total oak kill. However, the patches of oak that remain may benefit wildlife habitat, especially for lesser prairie chickens (Tympanuchus pallidicinctus).

We were able to convert a sand shinnery oak ecosystem to a mid-grass prairie; but this prairie has developed on easily erodable soils. More than 90,000 ha of sand shinnery oak have been treated with tebuthiuron. The resulting prairie may require different management strategies than the native oak-grass type.

\section{Literature Cited}

Deering, D., and R. Pettit. 1971. Sand shinnery oak acreage survey. Res. Highlights, Texas Tech Univ., Lubbock. 2:14.

Garrison, G.I., and K.C. MeDaniel. 1982. New Mexico brush inventory. New Mexico Dep. of Agr. Rep. No. 1.

Greer, H.A.I., E.H. McIlvain, and C.G. Armstrong. 1968. Controlling shinnery oak in western Oklahoma. Oklahoma State Univ. Ext. Facts No. 2765.

Jones, V.E., C.H. Meadors, and P.W. Jacoby. 1978. Pelleted herbicides for control of sand shinnery oak (Quercus havardii). Thirty First Meeting Soc. Range Manage., Proc. 31:59. (Abstr.).

Mcllvain, E.H. 1956. Shinnery oak can be controlled. Southern Weed Sci. Soc., Proc. 9:95-98.

Mcllvain, E.H., and C.G. Armstrong. 1959. Shinnery oak control produces more grass. Southern Weed Sci. Soc., Proc. 12:134-137.

Mcllvain, E.H., and C.G. Armstrong. 1963. Progress in shinnery oak and sand sage control at Woodward. U.S. Southern Great Plains Field Sta. Prog. Rep. 6301.

Table 1. Mean yield (kg/ha) of sand shinnery oak at study site in Cochran County, Texas, during 1978, 1979, 1980 and 1981 after tebuthiuron treatment in May 1978.

\begin{tabular}{|c|c|c|c|c|c|c|c|c|c|c|}
\hline \multirow{2}{*}{$\begin{array}{c}\text { Treatment } \\
(\mathrm{kg} / \mathrm{ha})\end{array}$} & \multicolumn{3}{|c|}{1978} & \multicolumn{3}{|c|}{1979} & \multicolumn{3}{|c|}{1980} & \multirow{2}{*}{$\frac{1981}{\text { Spring }}$} \\
\hline & Spring & Summer & Fall & Spring & Summer & Fall & Spring & Summer & Fall & \\
\hline 0.0 & $604 \mathrm{a}^{1}$ & $\square^{2}$ & 458 & - & $1041 \mathrm{a}$ & $906 \mathrm{a}$ & 1027 a & 781 a & $655 \mathrm{a}$ & $1149 \mathrm{a}$ \\
\hline 0.2 & $323 \mathrm{~b}$ & $\longrightarrow$ & - & - & $186 \mathrm{~b}$ & $166 \mathrm{~b}$ & $237 \mathrm{~b}$ & $293 \mathrm{~b}$ & $136 \mathrm{~b}$ & $346 \mathrm{~b}$ \\
\hline 0.4 & $462 \mathrm{ab}$ & $\longrightarrow$ & $\longrightarrow$ & $\longrightarrow$ & $53 \mathrm{c}$ & $41 c$ & $51 \mathrm{c}$ & $78 \mathrm{c}$ & $23 \mathrm{bc}$ & $46 c$ \\
\hline 0.6 & $436 \mathrm{ab}$ & $\longrightarrow$ & $\longrightarrow$ & $\longrightarrow$ & $25 \mathrm{c}$ & $1 \mathrm{c}$ & $39 c$ & $24 c$ & $18 \mathrm{bc}$ & $0 \mathrm{c}$ \\
\hline 0.8 & $350 \mathrm{~b}$ & . & $\longrightarrow$ & $\longrightarrow$ & $2 c$ & $0 \mathrm{c}$ & $15 c$ & $0 \mathrm{c}$ & $1 \mathrm{c}$ & $0 \mathrm{c}$ \\
\hline 1.0 & $332 \mathrm{~b}$ & - & $\cdots$ & $\longrightarrow$ & $0 \mathrm{c}$ & $0 \mathrm{c}$ & $2 c$ & $0 \mathrm{c}$ & $0 \mathrm{c}$ & $0 \mathrm{c}$ \\
\hline
\end{tabular}

'Means followed by a similar letter within the same column do not differ at the 0.05 level of probability.

2Data not available. 

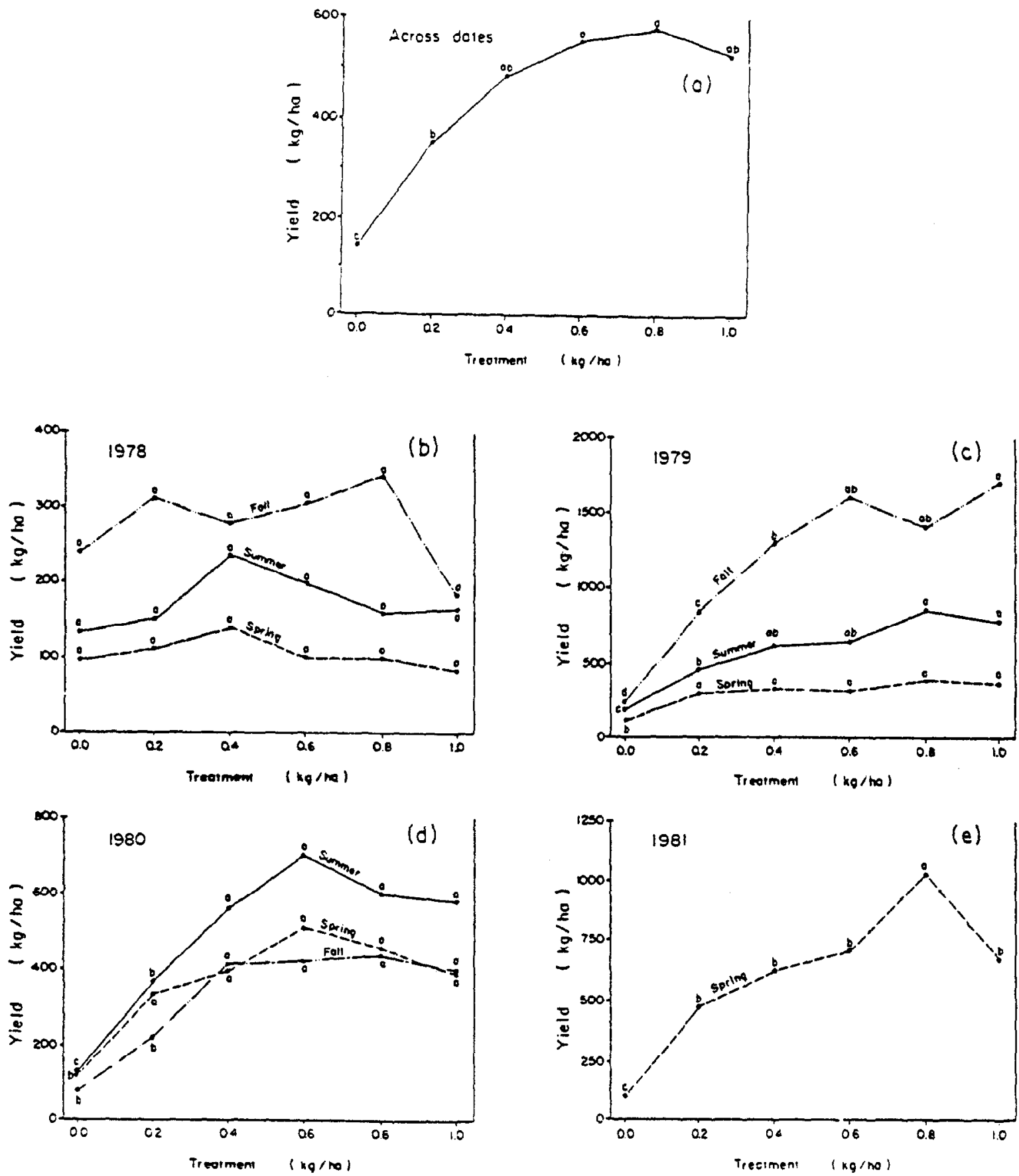

Fig. 1. Mean yield of grass both across dates (a) and by sampling date (b-e) at study site in Cochran County, Tex., following treatment with tebuthiuron in May 1978. Means on the same sampling date designed with the same letter are similar $(P<0.05)$.

Meyer, R.E., and R.W. Bovey. 1980. Control of live oak (Quercus virginiana) and understory vegetation with soil-applied herbicides. Weed Sci. 28:51-58.

Meyer, R.E., B.W. Bovey, and J.R. Bauer. 1978. Control of an oak (Quercus) complex with herbicide granules. Weed Sci. 26:444-453.

Pettit, R. 1975. Comparative effects of two pelleted herbicides on a shin oak community. Res. Highlights, Texas Tech Univ., Lubbock. 6:43.
Pettit, R.D. 1979. Effects of picloram and tebuthiuron pellets on sand shinnery oak communities. J. Range Manage. 32:196-200.

Scifres, C.J. 1972. Herbicide interactions in control of sand shinnery oak. J. Range Manage. 25:386-389.

Scifres, C.J., J.W.Stuth, and R.W. Bovey. 1981. Control of oaks (Quercus spp.) and associated woody species on rangeland with tebuthiuron. Weed Sci. 29:270-275.

Steel, R.G.D., and J.H. Torrie. 1960. Principles and procedures of statistics. McGraw-Hill Book Co., Inc., New York. 